\title{
Golden Section in Plain Radiograms of the Hip and Pelvis
}

\author{
Fujio Higuchi and Akihiro Daisaku \\ Department of Orthopaedic Surgery, Yanagawa Rehabilitation Hospital
}

\begin{abstract}
The golden ratio, or golden section, is an aesthetically pleasing mathematical ratio represented by the number 1.618. Examples of the beauty associated with this number are pervasive and can be witnessed in many aspects of life. Herein, the author would like to explore and elucidate the relevance of both the golden section and golden angle in plain radiograms of the hip and pelvis. While using plain standing radiograms, this study brought to light a total of five golden sections and three golden angles within the structure that composes the hip and pelvis. The author postulates that, due to sapient natural selection, a typical, healthy hip joint is made up of numerous golden sections and golden angles, making them not only beautiful to the human eye but, more importantly, allowing it a high functionality.
\end{abstract}

Key words: golden section (黄金比), hip joint (股関節), plain radiogram (レントゲン像), total hip arthroplasty（人工股関節置換術）

\section{Purpose:}

The golden ratio, or golden section, is an aesthetically pleasing mathematical ratio represented by the number 1.618. Examples of the beauty associated with this ratio exist not only in nature but in various fields such as mathematics, geography, biology, architecture, music, and astronomy. Leonardo da Vinci found evidence of what he called the "section aurea" or the golden section in the human body while performing his anatomical studies" $^{9}$. Herein, the author would like to explore the relevance of both the golden section and golden angle in plain radiograms of the hip and pelvis.

\section{Methods and Materials:}

The golden section is defined by the proportion 1:1.618 and is often associated with the Fibonacci numbers and their coinciding numerical sequence ${ }^{1)}$. The golden angle is the smaller of two angles created by sectioning the circumference of a circle using the golden ratio, namely 137.5 degrees. In this study, the author searched for evidence of both the golden section and golden angle in plain radiograms of the hip and pelvis taken of patients while in a standing position.

This study included a radiogram of a 52-year-old female patient (case 1) who complained of right hip pain without any known cause and an 87-year-old female patient (case 2) who had received a total hip arthroplasty 6 years earlier. The radiogram of the former patient revealed a mild case of dysplasia acetabuli without any other abnormality in the right hip and was given a diagnosis of acetabular rim syndrome ${ }^{8}$ following the MRI examination.

\section{Results:}

1. Evidence of the golden section was observed in both the femoral head and neck diameter. The femoral head diameter measured $44.3 \mathrm{~mm}$, while the neck was $27.5 \mathrm{~mm}$ in case 1 . These proportions were equal to 1.610 , which was extremely close to the golden section (Fig. 1). 


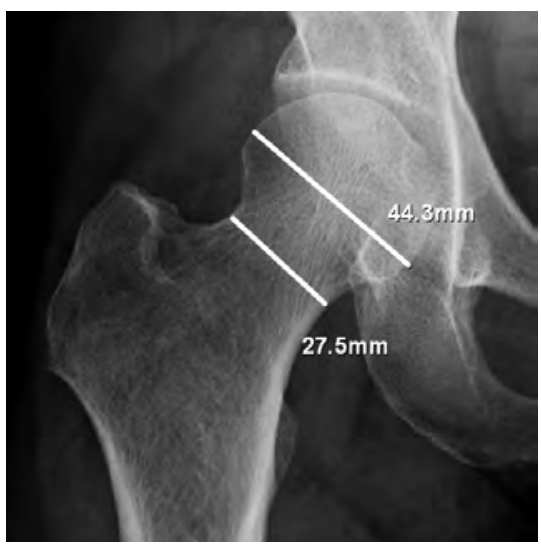

Fig. 1 The femoral head diameter measured $44.3 \mathrm{~mm}$, while the neck was $27.5 \mathrm{~mm}$ in case 1 . Their proportions were 1.610, which was extremely close to the golden section.

2. The horizontal distance from the medial end of the femoral head to the lateral end of the femoral head was $40.4 \mathrm{~mm}$, and the horizontal distance from the medial end of the femoral head to the center of the greater trochanter was $65.3 \mathrm{~mm}$ in case 1 , and these proportions were equal to 1.616 , which was almost equivalent to the golden section (Fig. 2).

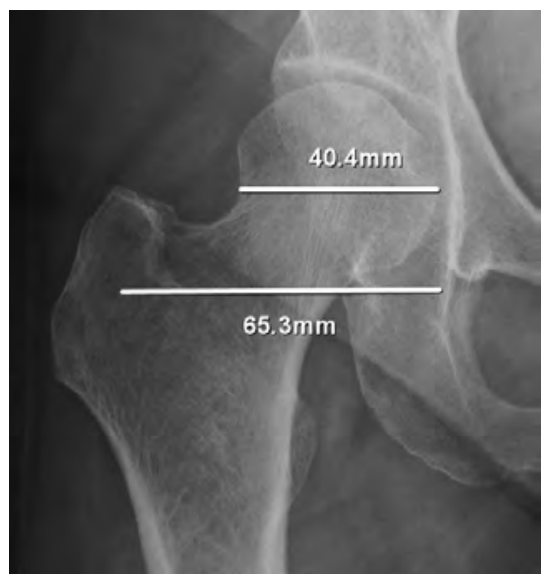

Fig. 2 The proportions of the horizontal distance from the medial end of the femoral head to the lateral end of the femoral head and the horizontal distance from the medial end of the femoral head to the center of the greater trochanter was equal to 1.616 , which was almost equivalent to the golden section.

3. The horizontal distance from the center of the symphysis pubis to the lateral end of the greater trochanter was $149.4 \mathrm{~mm}$, and from the center of the symphysis pubis to the center of the femoral head was $92.2 \mathrm{~mm}$ in case 1 . These proportions equaled 1.620, which resembled the golden section proportion. The author believes there may be a profound relationship between this proportion and the abduction function of the hip joint(Fig. 3). 


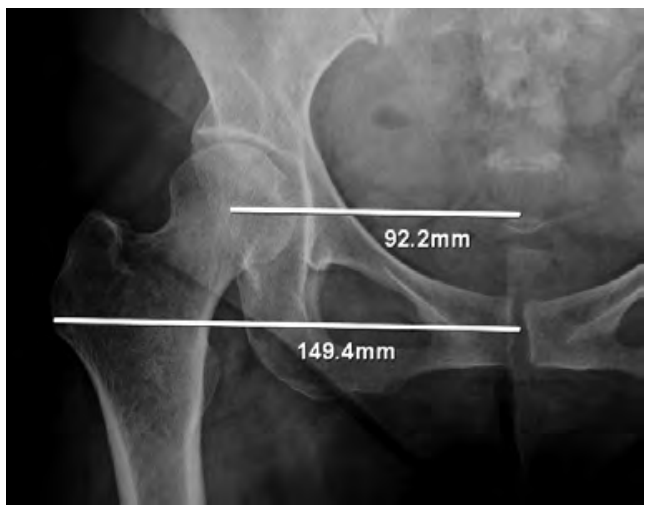

Fig. 3 The horizontal distance from the center of the symphysis pubis to the lateral end of the greater trochanter was $149.4 \mathrm{~mm}$, and from the center of the symphysis pubis to the center of the femoral head was $92.2 \mathrm{~mm}$. These proportions were equal to 1.620 , which resembled that of the golden section.

4. The longitudinal distance from the top of the femoral head to the bottom of the femoral head was $40.3 \mathrm{~mm}$, and from the top of the femoral head to the proximal end of the lesser trochanter was $65.3 \mathrm{~mm}$ in case 1 . These proportions equaled 1.620 which resembled that of the golden section. The author believes there may be a profound relationship between this proportion and the flexion function of the hip joint (Fig. 4).

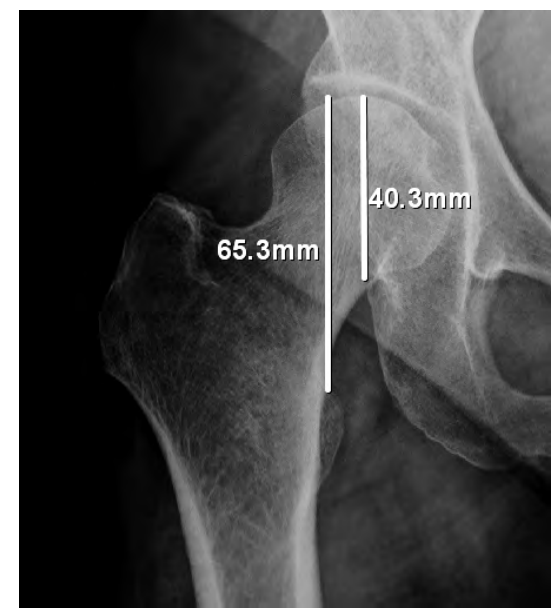

Fig. 4 The proportion of the longitudinal distance from the top of the femoral head to the bottom of the femoral head and from the top of the femoral head to the proximal end of the lesser trochanter was 1.620, which resembled that of the golden section.

5. The longitudinal distance from the top of the pelvic wing to the bottom of the symphysis pubis was $186.3 \mathrm{~mm}$, and the horizontal distance between the bilateral lateral ends of the greater trochanter was $301.2 \mathrm{~mm}$, with their proportions equaling 1.617, which was nearly the same as the golden section (Fig. 5). 


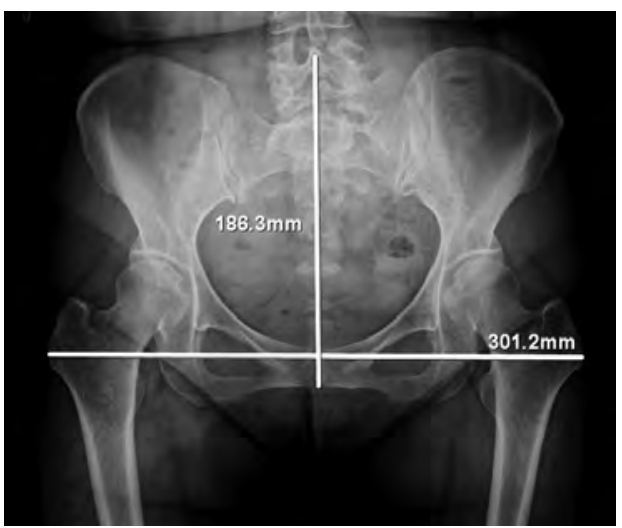

Fig. 5 The proportion of the longitudinal distance from the top of the pelvic wing to the bottom of the symphysis pubis and the horizontal distance between the bilateral ends of the greater trochanter equaled 1.617, which was nearly the same as the golden section.

6. Evidence of the golden angle was found in the femoral neck where the angle of the neck and shaft is commonly known to measure approximately 127 degrees, as was first documented by Pauwels ${ }^{10)}$; however, an angle figure of 137.5 degrees was overwritten on the proximal femur in the radiogram in case 1, aligning the neck-shaft angle with the golden angle (Fig. 6).

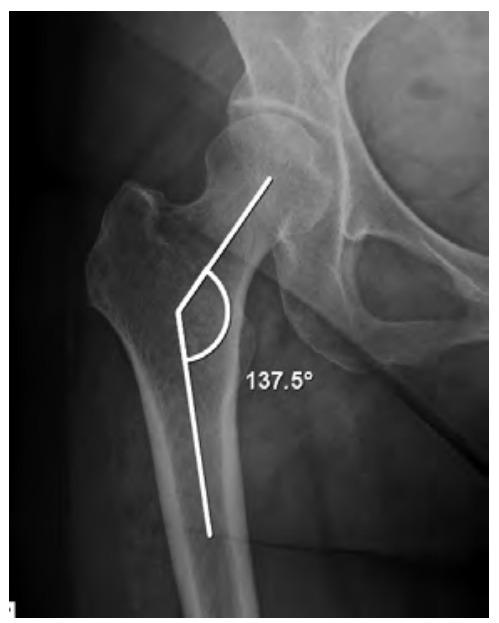

Fig. 6 An angle figure of 137.5 degrees was overwritten on the proximal femur in the radiogram in case 1, and the neck-shaft angle coincided with the golden angle.

7. The acetabular angle is the most important angle regarding hip radiograms, and in cases where the acetabular angle is too large, a diagnosis of hip dysplasia is made. In such cases, there is a potential for complaints of pain and further deterioration to the point of subluxation, while in cases where the acetabular angle is too much covering, there is a potential for complaints of hip pain resulting from impingement ${ }^{2}$. A normal acetabular angle, also known as Sharp's angle, was reported as being under 42 degrees, with anything over 47 degrees 
being considered dysplasia ${ }^{11)}$. The ideal Sharp's angle, where the hip's function is stable, is unknown; however, it most likely lies at approximately 42.5 degrees, making it the supplement to the golden angle (Fig. 7).

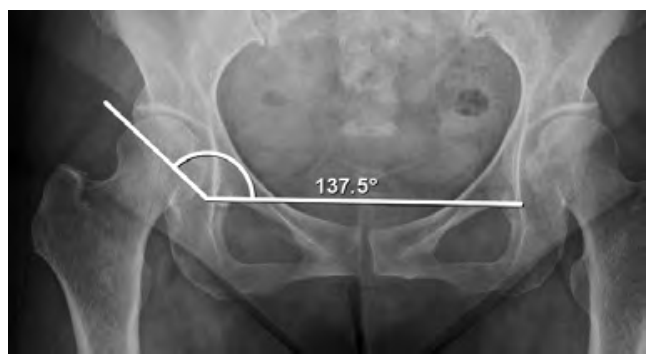

Fig. 7 This is the radiogram of case 1 who complained of right hip pain. When the golden angle was superimposed over the supplementary, or Sharp's angle, the presence of acetabular dysplasia became apparent and was subsequently diagnosed as acetabular rim syndrome after confirming a labrum tear using MRI.

8. In a healthy body, the promontory that is the center of the spine in the sacrum is located just above the hip center in lateral standing radiograms of the pelvis. This relationship may change because of pathological pelvic tilt in the sagittal plane in cases with either lumbar or hip disease ${ }^{12}$. The angle between the line from the hip center to the spina iliaca anterior superior and the parallel line along the femur's shaft was nearly equal to the golden angle (Fig. 8).

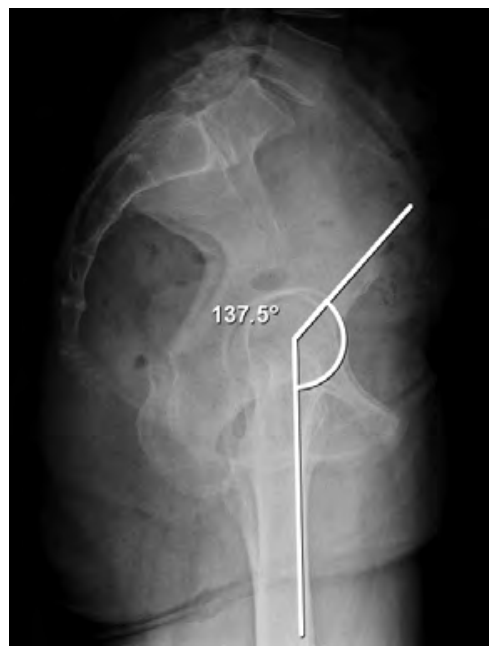

Fig. 8 The angle between the hip center and the spina iliaca anterior inferior and the parallel line along the femur's shaft is almost the same as the golden angle in lateral standing radiograms of the pelvis.

9. In over 2000 cases since the year 2000, the author has preferred using the SL stem designed by Zweymüller as a femoral component in total hip arthroplasty ${ }^{7}$. This preference is due to the stem's ability to endure prolonged usage without stem fracture and limited dislocation. Many orthopaedic surgeons see the shape of 
this stem as a work of exquisite beauty, with the probable reason being the neck-shaft angle's near equivalence to the golden angle (Fig. 9).

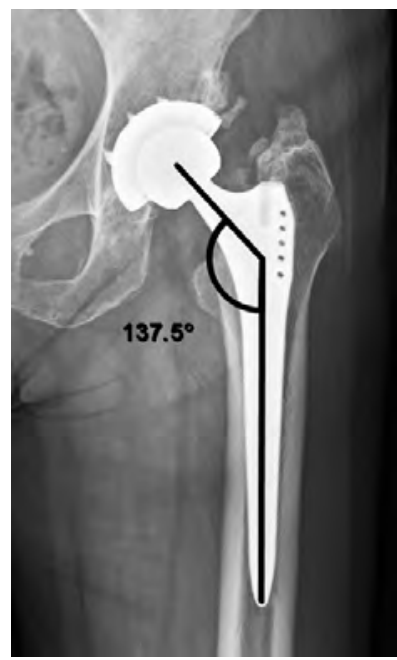

Fig. 9 The neck-shaft angle of the femoral stem designed by Zweymüller was nearly equivalent to the golden angle.

\section{Discussion}

With numerous mysteries remaining, the author has taken an active interest in the hip ${ }^{4)}$ and reported on its shape $^{5)}$ and the femoral head's gravity ${ }^{6)}$ in recent years. Furthermore, the author makes a point in considering the innate beauty of both the bone and the joint's shape relating to the hip. When orthopaedic surgeons see a pathological radiogram of the hip, this sense of beauty is lost, due to our understanding of the hip's deficient functionality. However, in radiograms of a healthy hip, this sense of beauty is indisputable to us, most likely due to the numerous golden sections and angles. In this study, there were many components involved in the total hip arthroplasty, and in some, the beauty of the femoral component was unmistakable. The author personally used stems designed by Zweymüller and was taken by the undeniable beauty seen in the resulting stem radiogram after total hip arthroplasty. The source of this beauty likely derives from the 136 degree angle built into the design of the neck shaft ${ }^{13)}$ and this angle's similarity to the golden angle.

The golden section's importance has been understood since the time of ancient Egypt, and in the $15^{\text {th }}$ century, Leonardo da Vinci first dubbed this section, the "sectio aurea". The ratio of the golden section is 1:1. 618. This number is intrinsically linked to the Fibonacci sequence and the golden spiral. The hidden numbers of this sequence are all around us and are seen in nature, plants, animals, insects, gene sequences, chemical formulae, the human body, paint, music, and planets ${ }^{9}$. The author searched for signs of the golden section in hip radiograms over the last few months, finding 5 golden sections and 3 golden angles. The author postulates that a typical, healthy hip joint containing numerous golden sections and golden angles must appear not only beautiful but also have high functionality as these proportions resulted from a sapient natural selection that developed over 2.5 million years ${ }^{3)}$. 
Conclusions: The author found 5 golden sections and 3 golden angles in the plain-standing radiograms of the hip and pelvis, which coincided with those found in the highly functioned artificial hip joint stem such as being designed by Zweymüller. These findings could prove beneficial in future orthopaedic research and joint surgery.

\title{
References
}

1) D'Agnese, J., O’Brien, J.: Fibonacci-A man who found the hidden number in nature, P.4-40. Japanese translation by Hiroko Shibuya, Eden Street LLC, New York, Saela Co. Tokyo, 2010.

2) Ganz, R., et al.: Femoro-acetabular impingement. An important cause of early osteoarthritis of the hip. Clin. Orthop. Relat. Res., 417: 1-9, 2003.

3) Harari, Y. N.: Sapience-A brief history of humankind: 4, Penguin Random House UK, 2014.

4) Higuchi, F.: Mysteries in the hip. 47 ${ }^{\text {th }}$ Hip Joint Column, Japanese Hip Research Society Home Page, (in Japanese) 2019.

5) Higuchi, F.: Why is the femoral head round? $14^{\text {th }}$ Hip Joint Column, Japanese Hip Research Society Home Page, (in Japanese) 2016 .

6) Higuchi F., Tanaka, K, Yoshimitu, K: Weight of the femoral head and femoral component in total hip arthroplasty. Seige to Saige 69: 18-19, (in Japanese) 2020.

7) Higuchi, F.: A mini-incision anterolateral approach for total hip arthroplasty using the SL-PLUS stem. 25 years of biologic fixation - K. Zweymüller, P.191-195. edited by Friederich NF \& Santore RF, München, Elsevier Urban \& Fisher, 2007.

8) Klaue, K., Durnin, C. W., Ganz, R.: The acetabular rim syndrome. A clinical presentation of dysplasia of the hip. J. Bone Joint Surg. Br., 73-B: 423-429, 1991.

9) Olsen, S.: The golden section- nature's greatest secret, P.1-65. Translated by Yuriko Fujita, Japanese translation published by arrangement with Bloomsbury Publishing Inc. Osaka, Sougensha Co. 2009.

10) Pauwels, F.: Atlas zur Biomechanik der gesunden und kranken Hüfte. Prinzipien, Technik und Resultate einer kausalen Therapie, P.9-17. Berlin, Spring-Verlag, 1973.

11) Sharp, I. K.: Acetabular dysplasia, the acetabular angle. J. Bone Joint Surg. Br. 43: 268-272, 1961.

12) Stephens, A. et al.: The kinematic relationship between sitting and standing posture and pelvic inclination and its significance to cup positioning in total hip arthroplasty. Int. Orthop., 39: 383-388, 2015.

13) Zweymüller, K.: SL-Plus cementless femoral hip system. Catalogue (in Japanese) : 11, Smith \& Nephew Orthopaedics K. K., Tokyo, 2008

$\langle$ 和文抄録〉

\section{股関節の中の黄金比}

\author{
柳川リハビリテーション病院整形外科 \\ 樋口富士男·大作 明 広
}

黄金比は，美術の中では美しい比率である，数学で は, フィボナッチ数列の前項と次項の比 $1: 1.618$ と 表現される。この数字 1.618 は, 幾何学, 生物学, 音 楽, 天文学にもみられる。黄金角は, 円の面積を二つ の半径で黄金比に分けた時の二つの半径の中心をなす 角 137.5 度である。この黄金比と黄金角を, 股関節の レントゲン像の中で探した.

股関節を含む立位骨盤の単純レントゲンの中に，黄 金比を 5 ヶ所, 黄金角を 3 ケ所に見出だした. Sharp
角と呼ばれる四蓋角は，黄金角の補角に当たる 42.5 度に該当した。黄金角は優れた機能の人工股関節のス テムにも見られた。

美しさを表す指標である黄金比，黄金角が，股関節 のレントゲン像にみられた. 人類の股関節は, 250 万 年の時を経て球形へと進化したが, 進化の過程で自然 淘汰を受けるので, 現在の形は機能的にも優れたもの である，黄金比のある股関節は，美しいだけでなく機 能の良い関節といえる。 